\title{
S Research Square \\ A study of bladder filling consistency before and during the radiotherapy for pelvic cancer
}

\section{Research}

Keywords: .

Posted Date: September 4th, 2021

DOI: https://doi.org/10.21203/rs.3.rs-96693/v2

License: (c) (i) This work is licensed under a Creative Commons Attribution 4.0 International License.

Read Full License 


\section{Abstract}

The full text of this preprint has been withdrawn by the authors because preprints are not widely accepted in China. Therefore, the authors do not wish this work to be cited as a reference. Questions should be directed to the corresponding author.

\section{Full Text}

The authors have withdrawn this preprint from Research Square. 